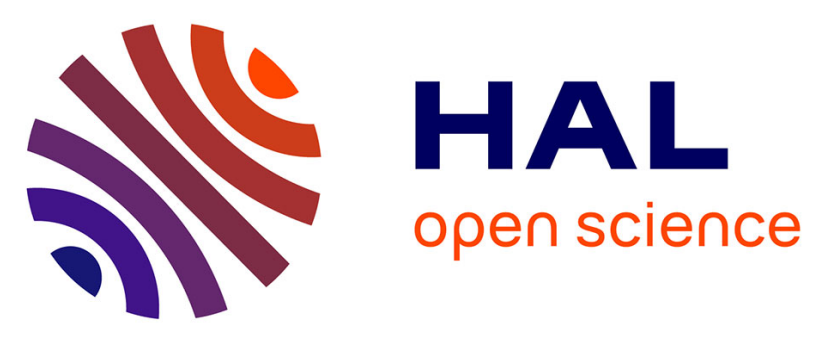

\title{
Sustainability of gastropod introduction for ecological engineering solution in infiltration basins: feeding strategy of V. viviparus
}

Valerian Estragnat, Laurence Volatier, Jean-Bastien Gambonnet, Frédéric Hervant, Pierre Marmonier, Florian Mermillod-Blondin

\section{To cite this version:}

Valerian Estragnat, Laurence Volatier, Jean-Bastien Gambonnet, Frédéric Hervant, Pierre Marmonier, et al.. Sustainability of gastropod introduction for ecological engineering solution in infiltration basins: feeding strategy of V. viviparus. Hydrobiologia, 2020, 847, pp.665-677. 10.1007/s10750-019-04128-6 . hal-02390994

\section{HAL Id: hal-02390994 https://univ-lyon1.hal.science/hal-02390994}

Submitted on 10 Dec 2020

HAL is a multi-disciplinary open access archive for the deposit and dissemination of scientific research documents, whether they are published or not. The documents may come from teaching and research institutions in France or abroad, or from public or private research centers.
L'archive ouverte pluridisciplinaire HAL, est destinée au dépôt et à la diffusion de documents scientifiques de niveau recherche, publiés ou non, émanant des établissements d'enseignement et de recherche français ou étrangers, des laboratoires publics ou privés. 
Sustainability of gastropod introduction for ecological engineering solution in infiltration basins: feeding strategy of $V$. viviparus

Authors

Valerian Estragnat*, Laurence Volatier (Laurence.Volatier@entpe.fr), Jean-Bastien Gambonnet (jeanbastien.gambonnet@developpement-durable.gouv.fr), Frédéric Hervant (Frederic.Hervant@univ-lyon1.fr), Pierre Marmonier (pierre.marmonier@univ-lyon1.fr), Florian Mermillod-Blondin (Florian.MermillodBlondin@univ-lyon1.fr),

*Corresponding author: valerian.estragnat@gmail.com;04 72448259

Univ Lyon, Université Claude Bernard Lyon 1, CNRS, ENTPE, UMR5023, Écologie des Hydrosystèmes Naturels et Anthropisés, Villeurbanne, F-69622, France

\section{Abstract}

The aim of this study was to test the sustainability of ecological engineering solutions based on the introduction of the gastropod $V$. viviparus in infiltration basins designed for groundwater recharge and clogged by benthic biofilms. This sustainability depends on the ability of gastropods to deal with variations in trophic resources throughout seasonal changes and so their feeding strategy. It is expected from literature that V. viviparus is a generalist species, well-adapted for ecological engineering approaches. With this objective, laboratory and field experiments were developed to measure the ability of gastropods to maintain energy body stores under several food sources and seasons, in relation with their physiological state. Our results showed that V. viviparus was not a strict generalist: it tended to be more efficient to constitute energy reserves when feeding on algae under laboratory conditions and its energy stores were positively correlated with primary productivity of the benthic biofilm in the field. Despite this higher efficiency of $V$. viviparus to produce energy reserves from algal resources, the survival and the levels of energy reserves measured on the field, even when trophic conditions 
were the harshest (low algal development), make this species a good candidate for ecological engineering approaches.

Key words

Trophic strategy, ecological engineering, biofilm, physiological state, gastropod, algae

\section{Acknowledgements}

We express our gratitude to Pauline Barbe and Mélissa Tenaille for their help during the collection of organisms and the experimentation, and to Laurent Simon and Félix Vallier who were involved in chemical analyses. Our thanks also go to Météo-France and Eau du Grand Lyon for the data they provided. This research was done on the Research Platform of Crépieux-Charmy (Plateforme de Recherche de Crépieux-Charmy) and received financial and technical support from the Lyon Metropole and Veolia Water (Eau du Grand Lyon). 


\section{Introduction}

Ecological engineering is a discipline aiming to use ecological theories to treat/ameliorate environmental issues. Ecological engineering approaches are often based on the introduction/manipulation of species diversity to modify environmental systems. For example, introduction of piscivorous species has been proposed to reduce eutrophication problems in lakes by trophic cascade effects (Carpenter et al., 1985). However, the maintenance of ecological engineering solutions on the long-term needs to evaluate the ability of introduced species to deal with environmental changes. Then, knowing the ecological strategies of introduced species is crucial to evaluate the sustainability of ecological engineering solutions.

The identification of feeding strategies is fundamental to the understanding of many ecological processes such as the flow of energy within food webs, the spatial distribution of species and the evolution of competitive interactions in communities (Bolnick et al., 2003; Holt, 2009; Poisot et al., 2011). Theory distinguishes generalist and specialist strategies, even though organisms employ a range of feeding strategies between these two extremes (Devictor et al., 2010; Futuyma and Moreno, 1988; Levins, 1968). Species with generalist strategies have a higher ability to endure environmental changes than organisms with specialist strategies (Clavel et al., 2011). For example, Devictor et al. (2008) showed that landscape disturbance would lead to a dominance of generalist individuals in bird populations.

Recently, we measured a positive influence of freshwater gastropod introduction to limit excessive development of benthic biofilm and its impact on the hydraulic performance of infiltration basins designed for groundwater recharge (Estragnat et al., 2018; Gette-Bouvarot et al., 2015). Experimentations were performed on biofilms developed under various environmental conditions (hydrological regime, nutrients fluxes, light availability) resulting in the formation of biofilms exhibiting contrasted structural and functional characteristics. However, all these experimentations were conducted during autumn season when chlorophyll- $a$ concentrations are the highest (more than $10 \mu \mathrm{g}$ of chlorophyll- $a$ per g of dry sediment in Gette-Bouvarot et al. 2015).

With seasonal changes and their effects on biofilm abundance, composition, primary production and metabolic balance (heterotrophs/phototrophs), the long-term sustainability of the introduction of the gastropod Viviparus viviparus (Linnaeus, 1758) needs to consider the feeding strategy of this organism under contrasting food sources availability. Recent findings demonstrated that $V$. viviparus was efficient to reduce clogging in infiltration basins characterized by variable quantities of food sources (bacterial-algal mat occurring on surface sediment, sedimentary biofilm and organic matter from surrounding vegetation) and suggested a low influence of food 
sources availability on gastropod feeding behaviour (Estragnat et al. 2018). This supposition was consistent with the study of Jakubik (2009) which reported that the mass and composition of foods ingested by V. viviparus mainly depended on the availability and abundance of food sources in the environment. This study, performed in lotic and lentic freshwater environments between 1995 and 2006, also indicated that $V$. viviparus could significantly feed on low-energetic food sources such as detritus. Indeed, detritus could represent 70 to $90 \%$ of the food mass ingested by the gastropod whatever the season or the habitat (river, reservoir, lake). All this information suggests that $V$. viviparus has a generalist feeding behaviour favouring the development of this species in contrasted trophic environments and thus making $V$. viviparus a good candidate for ecological engineering approaches. However, this hypothesis has to be tested by evaluating the ability of $V$. viviparus to maintain its physiological state under different food sources. Among the parameters that can be measured to assess physiological state, the reserve in triglycerides of an organism can be considered as a good proxy, because it is the major form of energy storage in gastropods (Gust et al. 2011) and free lipids (mainly triglycerides) have been shown to be correlated with the growth rate of aquatic snails (Hill et al. 1992).

To test the hypothesis that $V$. viviparus is a generalist species, we used a combination of laboratory and in situ experiments. First, laboratory microcosms were used to quantify to what extent different food sources affect reserve in triglycerides of gastropods. To this end, gastropods were fed ad libitum on three food sources: two sources found in natural environments (algal mat and sedimentary biofilm) and one control food used for gastropod breeding (Tetramin ${ }^{\circledR}$ goldfish flakes). We also measured the oxygen consumption rate to determine whether gastropod metabolism has been impacted by food source. Then, we used in situ enclosures within infiltration basin to track seasonal changes in triglyceride reserve of gastropods depending on various quality and quantity of available food resource. Under the hypothesis that $V$. viviparus is a generalist species, gastropods would have the same triglyceride concentrations whatever the season, i.e. the proportion of heterotrophic (sedimentary biofilm) and phototrophic (algal mat) benthic food sources.

\section{Materials and Methods}

Study site

The experiment was set up in the pumping well field of "Crépieux-Charmy" which provides drinking water for the metropolitan area of Lyon. Infiltration basins have been excavated to recharge the aquifer with surface water from the "Vieux Rhône" channel of the Rhône River. The field experiment was performed in a basin, in which the 
water column was maintained independently of the usual site management, during the entire course of the experiment. Sedimentary biofilm and algal mat used in laboratory experiment were also collected from this basin.

\section{Model species}

The studied species was V. viviparus, a prosobranch gastropod. Literature shows that V. viviparus are filter-feeders in phytoplankton-rich environments but they clearly switch to grazing behavior in environments characterized by low phytoplankton concentrations (Cook, 1949 ; Höckelmann and Pusch, 2000) as observed in our study site. Indeed, the chlorophyll- $a$ concentrations in the water column of the studied basin never exceeded $7 \mu$ g.L.-1 whatever the season in 2016, 2017 and 2018 (data from Eau du Grand Lyon). Specimens were collected in a cut off channel of the Rhône River. Before laboratory and field experiments, gastropods were kept during six months in 20 litre glass aquariums (15 specimens per aquarium) under controlled laboratory conditions following the studies of Cook (1949) and Tsvetkov et al. (2003): water temperature $\left(18^{\circ} \mathrm{C}\right)$, lightening condition (12:12 h light:dark regime), aerated water (ambient air bubbling) and regular water replacement (50\% of the volume once a week). Animals were fed each week with Tetramin ${ }^{\circledR}$ goldfish flakes. These laboratory conditions were favourable as the survival of $V$. viviparus was more than $99 \%$ after 3 months of acclimation. The gastropods used in this experimentation were mature and had total shell height comprised between 20 and $30 \mathrm{~mm}$. We used a sex ratio of 2 males for 1 female in the experiments to fit with the sex ratio observed during animal collection. Although triglyceride concentrations often varied between males and females in aquatic invertebrate species, preliminary experiments showed that no difference in triglyceride concentrations was observed between males and females of V. viviparus (Online Resource 1).

\section{Laboratory experiment}

\section{Experimental design}

The laboratory experiment was conducted in 36 glass aquariums $(21 \mathrm{~cm}$ in length $\mathrm{x} 10 \mathrm{~cm}$ in depth $\mathrm{x} 20 \mathrm{~cm}$ in height). The experiment lasted six weeks under the same laboratory conditions than those used for animal maintenance before the experiments (see paragraph 2.2). We selected an experimental duration of 6 weeks to fit with the feeding experiments performed by Hill et al. (1992) on aquatic snails. The aquariums were filled with tap water previously dechlorinated by air bubbling during two days. One centimetre of sand collected from a terrestrial quarry having a grain size distribution comparable to those of sand in the field (Gette-Bouvarot et al., 2014) and presenting low organic matter concentrations (Table 1) was placed in the bottom of each aquarium. Three gastropods previously maintained in dechlorinated water to clean their gut content were introduced in each 
aquarium. Then, a density of 142 individuals. $\mathrm{m}^{-2}$ was tested to be in the range of $V$. viviparus densities observed in the field (Jakubik, 2012).

Three food treatments were applied and randomly distributed among the aquariums (12 replicated aquariums per food treatment):

(i) Breeding food: Tetramin ${ }^{\circledR}$ goldfish flakes (the positive control)

(ii) Algal mat (predominantly phototrophic) collected within the studied basin by scraping the upper $5 \mathrm{~mm}$ layer of illuminated sediments

(iii) Sedimentary biofilm (predominantly heterotrophic) collected in the studied basin by sampling a $5 \mathrm{~mm}$ layer of non-illuminated sediments $(1 \mathrm{~cm}$ above the surface)

Natural food sources (algal mat and sedimentary biofilm) were freshly collected in the field at the start of the experiment and introduced in aquariums to cover the bottom sand layer. Additional samples of food sources were stored at $4^{\circ} \mathrm{C}$ to constitute a fresh stock for food replacement during the experiment. Food was added (flakes) or replaced (algal mat and sedimentary biofilms) ad libitum once a week (i.e., we observed that animals never consumed the totality of each food source during a week).

These different foods were characterized by their elemental composition in C, N and P (Table 1). Total organic carbon (TOC) and total nitrogen were measured with an elemental analyzer (FlashEA, Thermo Electron Corporation). Total phosphorus concentrations of foods were determined following the method of Murphy and Riley (1958). We measured the following decreasing gradient of nitrogen, organic carbon and phosphorus contents among the 3 food sources: breeding food > algal mat > sedimentary biofilm (Table 1). It is worth noting that the sand at the bottom of the aquariums was very poor in these elements (more than 15 fold lower in $\mathrm{N}$, organic $\mathrm{C}$ and P than sedimentary biofilm) and cannot be considered as a valuable food source for gastropods.

Controls of physical and chemical conditions were performed in each aquarium every week. Temperature, $\mathrm{pH}$, dissolved oxygen and electric conductivity were measured with a HQ40 multiparametric probe $(\mathrm{HACH})$ and nutrient concentrations $\left(\mathrm{N}-\mathrm{NO}_{2}{ }^{-}, \mathrm{N}-\mathrm{NO}_{3}{ }^{-}, \mathrm{N}-\mathrm{NH}_{4}{ }^{+}\right.$and $\left.\mathrm{P}-\mathrm{PO}_{4}{ }^{3-}\right)$ with a sequential analyser (SmartChem 200, AMS Alliance, Frépillon, France) using colorimetric methods (Grasshoff et al., 1983). Comparable physical and chemical conditions were measured in the aquariums during the course of the experiment with mean values of 18.6 $\pm 0.1{ }^{\circ} \mathrm{C}, 8.4 \pm 0.1,9.4 \pm 0.1 \mathrm{mg} . \mathrm{L}^{-1}, 340 \pm 20 \mu \mathrm{S} . \mathrm{cm}^{-1}, 0.14 \pm 0.08 \mathrm{mg} . \mathrm{L}^{-1}, 2.67 \pm 0.70 \mathrm{mg} . \mathrm{L}^{-1}, 0.11 \pm 0.07 \mathrm{mg} . \mathrm{L}^{-}$ 
1 and $0.06 \pm 0.03 \mathrm{mg} . \mathrm{L}^{-1}$ (mean \pm standard deviation) for temperature, $\mathrm{pH}$, dissolved oxygen, electric conductivity, $\mathrm{N}-\mathrm{NO}_{2}{ }^{-}, \mathrm{N}-\mathrm{NO}_{3}{ }^{-}, \mathrm{N}-\mathrm{NH}_{4}{ }^{+}$and $\mathrm{P}-\mathrm{PO}_{4}{ }^{3-}$, respectively. Sampling

For each measured variable (triglyceride concentrations and oxygen consumption rates) and time of experiment (start, 2, 4 and 6 weeks), twelve individuals were used. Gastropods were analysed individually to obtain 12 replicates per date and treatment for each variable. Then, a total of 120 individuals (12 at the start and 108 during the experiment) were used for the laboratory experiment.

\section{Measurements performed on V. viviparus}

For oxygen consumption rates, the shells of the snails were gently cleaned before the measurements to remove biofilm development, to ensure that an overshoot in oxygen uptake due to biofilm metabolism did not affect the results. Then, each individual was placed in $250 \mathrm{~mL}$ watertight container filled with aerated dechlorinated water (about $9 \mathrm{mg} . \mathrm{L}^{-1}$ of dissolved oxygen) for 4 hours under dark conditions. Dissolved oxygen measurements were made with an inoLab Oxi 7310 (WTW, Xylem Analytics) at the start and the end of the incubation to determine the consumption of oxygen during the 4 hours. Oxygen consumption was expressed as consumption of dissolved oxygen per hour and per gram of dried mass.

Before triglyceride measurements, each individual was placed in a beaker filled with dechlorinated tap water to empty its digestive tract. Then, animals were frozen, lyophilised and homogenized with a ball mill. Triglycerides were extracted from $30 \mathrm{mg}$ of homogenized tissues (from the whole organism) according to the methods of Barclay et al. (1983) and Elendt (1989), and then evaluated using specific test-combinations (Boehringer-Mannheim) (triglyceride levels were measured by determining glycerol released from triglycerides hydrolysis). All assays were performed in a recording spectrophotometer (Beckman DU-6) at $25^{\circ} \mathrm{C}$. Enzymes, coenzymes and substrates used for enzymatic essays were purchased from Boehringer (Mannheim, Germany) and Sigma Co. (St Louis, USA). Triglyceride concentrations were expressed as mg of glycerol per $\mathrm{g}$ of dried mass.

\section{Field experiment}

\section{Experimental design and sampling}

Experimentations were performed at different periods to test the trophic response of gastropods to contrasted biofilm characteristics at the water-sediment interface. The experiment consisted of four periods of 6 weeks in October 2016, February 2017, June 2017 and April 2018. Two periods were characterized by elevated 
photoperiods and global hourly radiations which were favourable to the development of phototrophic organisms (June 2017 and April 2018), compared to the other periods (October 2016 and February 2017). Physical and chemical variables were measured to characterize each period. The photoperiod and the global hourly radiation have been obtained from Météo-France. Temperature and the water level were measured every 15 minutes with a water level logger Diver (Schlumberger Water Sciences, The Netherlands). Nutrient concentrations were weekly measured and obtained from filtered water $(0.7 \mu \mathrm{m})$ conserved at $4{ }^{\circ} \mathrm{C}$ before analysis within $24 \mathrm{~h}$ with sequential analyser (SmartChem 200, AMS Alliance, Frépillon, France) using colorimetric methods (Grasshoff et al., 1983). Conductivity, dissolved oxygen and $\mathrm{pH}$ were also weekly measured with a Ponsel Odeon data logger and the associated probes (Aqualabo Contrôle, France).

Photoperiods were 10.6, 11.4, 15.8, and 14.4h for October 2016, February 2017, June 2017 and April 2018, respectively. Global hourly radiations were 33.0, 46.9, 96.0, and 77.5 joules.cm² for October 2016, February 2017, June 2017 and April 2018, respectively. Temperatures were 16, 11, 20, and $16^{\circ} \mathrm{C}$ for October 2016, February 2017, June 2017 and April 2018, respectively. The mean water levels varied among the periods between 90 and $120 \mathrm{~cm}$. Respectively, nutrient concentrations were inferior to $1.1 \mathrm{mg} . \mathrm{L}^{-1}, 24.9 \mu \mathrm{g} . \mathrm{L}^{-1}$ and $13.5 \mu \mathrm{g} . \mathrm{L}^{-1}$ for N-NOx, N-NH${ }_{4}^{+}$ and $\mathrm{P}_{-} \mathrm{PO}_{4}{ }^{3-} \cdot \mathrm{pH}$, electric conductivity and dissolved oxygen ranged between 7.3 and 8.4, 298.7 and $351.7 \mu \mathrm{S} . \mathrm{cm}^{-}$ ${ }^{1}$, and 8.2 and $12.7 \mathrm{mg} \cdot \mathrm{L}^{-1}$, respectively.

For each period, six in situ enclosures (see the description in Gette-Bouvarot et al., 2015 \& Estragnat et al., 2018) with 5 V. viviparus were used in the infiltration basin. Briefly, enclosures consisted of stainless steel cylinders (internal diameter of $30 \mathrm{~cm}$ and height of $14 \mathrm{~cm}$ ) firmly buried in the sediment at a depth of $11 \mathrm{~cm}$ and covered with nylon nets $(0.5 \mathrm{~cm}$ mesh size $)$ to avoid the escape of the gastropods. For data independence, different enclosures with different positions were used for each of the four periods. Ten individuals were used to assess the triglyceride concentrations at the beginning of each period. A total of 160 individuals were used for the field experiment. A density of 71 individuals. $\mathrm{m}^{-2}$ was introduced per enclosure to mimic natural densities observed in freshwater habitats. Measurements were performed at the start and at the end (6 weeks) of the experiment to determine biological structural characteristics (algal biomass and total organic carbon) and functional characteristics (net photosynthetic activity, respiration) of the sedimentary interface for each enclosure. The top layer $(0-1 \mathrm{~cm})$ of sediments was randomly sampled in each enclosure at the start of the experiment and after 6 weeks of experimentation by coring using cut syringes (internal diameter $=15 \mathrm{~mm}$ for structural characteristics and internal diameter $=20 \mathrm{~mm}$ for functional characteristics). Fifteen samples were collected, mixed and homogenized per enclosure to obtain representative one sediment sample for each enclosure and date (start and 6 
weeks), for the structural characteristics of the sedimentary interface. In addition, two intact cores were collected for the functional characteristics of the sedimentary interface. Sampling was conducted with sufficient water level in the basin, to prevent any drying and disturbance of sediment and biofilm. All samples were then stored in a cool box during transport to the laboratory within $4 \mathrm{~h}$.

\section{Biological characteristics}

The phototrophic biomass of the sediment biofilm was assessed by measuring chlorophyll- $a$ content on frozen sediment by spectrophotometry using the SCOR-UNESCO method (UNESCO, 1966). The phototrophic biomasses were expressed as $\mu \mathrm{g}$ of chlorophyll- $a$ per gram of dried sediment.

Total organic carbon (TOC) was measured on lyophilised sediment as an estimator of the sedimentary biofilm biomass. According to Mermillod-Blondin et al. (2015), TOC was determined by high-temperature combustion of in situ pre-acidified dry samples $\left(60^{\circ} \mathrm{C}, 48 \mathrm{~h}\right)$ and subsequent measurement of $\mathrm{CO}_{2}$ by thermal conductometry using an elemental analyser (FlashEA, Thermo Electron Corporation). The TOC was expressed as the percentage of organic carbon in each sample.

The Benthic Trophic State Index (BTSI) was assessed using comparison between net photosynthetic activity (NPA) and respiration (RES). This index is a metabolism-based trophic index for comparing the ecological values of shallow-water sediment habitats (Rizzo et al., 1996) and is divided in four classes: $0=$ totally heterotrophic $(\mathrm{NPA} \leq \mathrm{RES}), 1=$ net heterotrophic $(\mathrm{RES}<\mathrm{NPA} \leq 0), 2=$ net phototrophic $(0<\mathrm{NPA} \leq|\mathrm{RES}|)$ and $3=$ highly autotrophic $(|\mathrm{RES}|<\mathrm{NPA})$. The net photosynthesis rates were obtained by measuring the oxygen production on fresh sediment under illumination (irradiance of $150 \mu \mathrm{mol} . \mathrm{m}^{-2} \cdot \mathrm{s}^{-1}$ ) and the respiration was obtained by measuring the oxygen uptake in the dark. For each sample, oxygen production and uptake were obtained at $15^{\circ} \mathrm{C}$ using 150 $\mathrm{mL}$ airtight glass bottle filled with filtrated water $(0.22 \mu \mathrm{m})$ from the infiltration basin. Oxygen production and uptake were measured with an inoLab Oxi 7310 (WTW, Xylem Analytics) at the start and the end of the incubation. Oxygen production and uptake were expressed as consumption of dissolved oxygen per hour and per gram of dried organic matter.

\section{Triglyceride analyses performed on gastropods}

Triglyceride concentrations were measured at the start and the end of the experiment according to the method presented for the laboratory experiment (see section 2.3.4). At the start of the experiment, triglyceride 
concentrations of gastropods previously maintained in laboratory were $0.0038 \pm 0.0016$ (mean \pm standard deviation) $\mathrm{mg}$ of glycerol per mg of dried mass.

\section{Statistical analyses}

For the laboratory experiment, the influence of the food treatment on triglyceride concentrations and oxygen consumption were assessed using two-way analyses of variance (ANOVA II), with treatment (food source) and time as fixed factors. Then, subsequent Tukey’s tests were performed to determine which treatments differed. Pearson's correlation tests were performed between the triglyceride concentrations at the end of the experiment and the three food elements that were measured (total organic carbon, total nitrogen and phosphorus).

For the field experiment, the influence of the period on triglyceride concentrations, TOC, chlorophyll- $a$ concentrations and the BTSI were assessed using one-way analyses of variance (ANOVA I), with period as fixed factor. To evaluate the link between food sources and triglyceride concentration in gastropods, Pearson's correlation tests were performed between triglyceride concentrations measured at the end of the experiment and the three proxies of food source availability (TOC concentrations, chlorophyll- $a$ concentrations and the BTSI).

For all variables, the normality and the homoscedasticity of the residues were tested using the Shapiro-Wilk's test and the Levene's test, respectively. All statistical analyses were performed using R software (R Development Core Team, 2008). Significance for statistical tests was accepted for a first species risk set at $\alpha<0.05$ considering a bilateral risk.

Results

\section{Laboratory experiment}

At the start of the experiment the triglyceride concentration of gastropods was $0.0027 \pm 0.0010$ (mean \pm standard deviation) $\mathrm{mg}$ of glycerol per g of dry mass. Triglyceride concentrations increased from week 2 to week 6 in all food treatments (Figure 1.A, ANOVA II, “time" effect, $F_{2,99}=4.57, \mathrm{p}=0.013$ ). A significant difference in triglyceride concentrations was measured among food treatments (ANOVA II, "treatment" effect, F $2,99=17.98, \mathrm{p}$ $<0.0001)$ : triglyceride concentrations in gastropods were the highest with the breeding food and the lowest with sedimentary biofilm. Triglyceride concentrations for gastropods fed on algal mat were intermediate with concentration lower than those of gastropods fed with breeding food (Tukey's test, algal mat/breeding food differences, $\mathrm{p}<0.001)$. Although the statistical test was not significant at $5 \%$, gastropods fed with algal mat tend 
to have higher triglyceride concentrations than those fed with sedimentary biofilm (Tukey's test, algal mat/sedimentary biofilm differences, $\mathrm{p}=0.08)$. No significant interaction between "time" and "treatment" effects on triglyceride concentrations was measured (ANOVA II, "treatment*time" effect, $\mathrm{F}_{4,99}=2.28, \mathrm{p}=0.065$ ).

At the start of the experiment, the oxygen consumption rate of gastropods was $0.35 \pm 0.09$ (mean \pm standard deviation) $\mathrm{mg}$ of dissolved oxygen per hour and per gram of dry mass. Oxygen consumption rates significantly decreased from week 2 to week 6 (ANOVA II, "time" effect, $F_{2,86}=5.01, p=0.009$ ) but this decrease seemed more pronounced in the treatment with sedimentary biofilm than in other treatments (Figure 1.B). Despite no statistically significant differences among food treatments (ANOVA II, "treatment" effect, $\mathrm{F}_{2,86}=2.23, \mathrm{p}=0.11$ ), the oxygen consumption rates of gastropods fed on sedimentary biofilm tended to be lower than those measured in the two other treatments after 6 weeks of experiment (Figure 1.B). No significant interaction between "time" and "treatment" effects on oxygen consumption rates was measured (ANOVA II, "treatment*time" effect, $\mathrm{F}_{4,86}=$ $0.86, \mathrm{p}=0.49)$.

The link between energy reserves of gastropods and the elemental compositions of food sources was clearly shown by the positive correlations obtained between triglyceride concentrations in gastropods measured after 6 weeks of experimentation and the concentrations of TOC (Pearson's correlation, $\mathrm{R}=0.69, \mathrm{t}=5.61$, $\mathrm{df}=34, \mathrm{p}<0.0001$ ), total nitrogen (Pearson's correlation, $\mathrm{R}=0.70, \mathrm{t}=5.73, \mathrm{df}=34, \mathrm{p}<0.0001$ ) and total phosphorus (Pearson's correlation, $\mathrm{R}=0.70, \mathrm{t}=5.65, \mathrm{df}=34, \mathrm{p}<0.0001)$ in food sources.

\section{Field experiment}

The mean Chlorophyll- $a$ and TOC concentrations of the sedimentary interface measured from 6 enclosures (based on one value per enclosure calculated from measures performed at the start and the end of the experiment) were significantly different among periods (Figure 2.A\&B ANOVA I, "period" effect, $\mathrm{F}_{3,116}=82.85$ for the chlorophyll$a$ concentration and $\mathrm{F}_{3,116}=30.10$ for TOC concentration, $\mathrm{p}<0.0001$ for the two variables) with highest values measured in June 2017, which was the most favourable period for the development of phototrophic organisms.

Mean BTSI values were comprised between 2 and 3 (i.e. net phototrophic to highly phototrophic states) for all seasons at the exception of October 2016 during which BTSI values were lower (between 1 and 2) indicating variations between net heterotrophic to net phototrophic states (Figure 2.C, ANOVA I, "period" effect, $\mathrm{F}_{3,116}=$ $34.33, \mathrm{p}<0.0001)$. 
Significant differences were observed among the periods for triglyceride concentrations in gastropods (Figure 3, ANOVA I, "period" effect, $\left.F_{3,116}=17.83, \mathrm{p}<0.0001\right)$. Surprisingly, triglyceride concentrations were the lowest in October 2016 and June 2017, which were the most contrasted periods for chlorophyll- $a$ concentrations at the sedimentary interface (Figure 2.A). Indeed, no positive correlation was observed between triglyceride concentrations in gastropods after 6 weeks of experimentation and chlorophyll- $a$ concentrations at the interface (Figure 4.A; Pearson's correlation, $\mathrm{R}=-0.2, \mathrm{t}=-2.22, \mathrm{df}=118, \mathrm{p}=0.03$ ). We also did not detect a positive correlation between triglycerides concentrations in gastropods after 6 weeks of experimentation and TOC concentrations at the interface (Figure $4 \mathrm{~B}$, Pearson's correlation, $\mathrm{R}=-0.11, \mathrm{t}=-1.19$, $\mathrm{df}=118, \mathrm{p}>0.05$ ). In contrast, the metabolic-based trophic status (BTSI) was positively correlated to triglyceride concentrations in gastropods after 6 weeks of experimentation (Figure $4 \mathrm{C}$, Pearson's correlation, $\mathrm{R}=0.33, \mathrm{t}=3.87, \mathrm{df}=118, \mathrm{p}<$ 0.001), suggesting a positive influence of the phototrophic primary production on the ability of gastropods to constitute energy reserves. From the comparison between field and laboratory experiments, it is also worth noting that triglyceride concentrations measured on gastropods enclosed in the field were around 2-fold higher than concentrations measured for gastropods feeding on algal mat and sedimentary biofilm in the laboratory experiment (see Figure 1.A).

\section{Discussion}

Our results provided evidences that $V$. viviparus could not be considered as a strict generalist in our experiments. Indeed, $V$. viviparus tended to more efficiently constitute energy reserves on algal mat than on sedimentary biofilm in laboratory. In parallel, oxygen consumption rates of gastropods tended to be lower after feeding on sedimentary biofilms than on algal mats, indicating an effect of food type on the metabolism of $V$. viviparus. These results suggest a lower food consumption rate for $V$. viviparus feeding on sedimentary biofilm than on algal mat. Moreover, the fact that triglyceride concentrations in gastropods measured in the field were positively correlated with BTSI suggested a positive influence of phototrophic primary production on the constitution of energy reserves in V. viviparus. Thus, both laboratory and field experiments showed that phototrophic food sources (algal mat), and most particularly active algal mat, were energetically more favourable for gastropods than heterotrophic food sources (sedimentary biofilm).

The laboratory experiment specifically highlighted that the efficiency of gastropods to constitute energy stores among food sources was positively correlated to food nutrient $(\mathrm{C}, \mathrm{N}, \mathrm{P})$ concentrations. This relationship was most likely due to the equilibrium between the nutrient supplied by the food sources and the energy demand needed to 
acquire these nutrients: gastropods feeding on sedimentary biofilm had to ingest more food (in terms of mass) to acquire the same amount of nutrients compared to those feeding on algal mat. Previous studies reported an increase in the rate of food ingestion by aquatic grazers as a behavioral response to acquire energy from low-nutrient food sources (Fink and Von Elert, 2006; Flores et al., 2014). For example, Calow (1975) reported an inverse relationship between the ingestion rate of freshwater benthic organisms and food quality: animals compensated for less nutritive food by increasing their feeding rates. Cruz-Rivera and Hay (2001) also observed that the marine amphipod Ampithoe longimana increased its food consumption as the total organic matter content in algae declined. However, in the present laboratory experiment, the decrease in oxygen consumption measured on V. viviparus fed with sedimentary biofilms more likely suggests a physiological response rather than a behavioral feeding response of gastropods to a low-nutritive food source. More precisely, gasteropods tended to reduce their metabolic rates (i.e. to enter in a prolonged state of torpor) rather than increase their food acquisition to maintain their energy budget. The present study is the first to report this metabolic response of $V$. viviparus to low-nutrient food sources, although such response has already been reported for other aquatic invertebrates such as gammarids which can adjust their respiration rates to food quality (Graça et al. 1993). Moreover, our interpretation is consistent with the laboratory observations of Cook (1949) who reported that $V$. viviparus can be inactive and partially buried within sediments during several days.

Field measurements showed that the triglyceride concentrations of gastropods were positively correlated with BTSI whereas it was not the case with chlorophyll- $a$ concentrations. This result indicates that the photosynthetic activity of the algal biofilm (associated with BTSI) had more impact on the production of energy reserves in gastropods than the algal biomass of the biofilm. This interpretation is consistent with the fact that the photosynthetic activity of the biofilm positively influences the production of extracellular polymeric substances (EPS) which can be high nutritional compounds for invertebrates (e.g., Decho, 1990; Decho and Moriarty, 1990). Indeed, photosynthetic activities and algal growth have been particularly related to the secretion of EPS (Staats et al., 2000; Barranguet et al., 2005). In active biofilms, microbial cells secrete EPS which mainly consists of carbohydates and proteins (Stewart et al., 2013, Costa et al. 2018). For example, Fang et al. (2014) measured a total content in EPS close to $13 \mathrm{mg} / \mathrm{g}$ of dried weight containing $67 \%$ of carbohydrates and $25 \%$ of protein (w: $w)$ in a lake phototrophic biofilm. Depending on environmental conditions (light, nutrient concentrations), Bellinger et al. (2010) also reported that carbohydrate concentrations in EPS varied between 20 and $60 \%$ (w:w) in phototrophic biofilms from freshwater wetlands. Therefore, under the varying environmental conditions observed in our field study, BTSI was likely associated with the production of EPS which contributed to the nutritional 
quality of biofilms for algal grazers. As a consequence, we measured a positive correlation between the energy reserves of $V$. viviparus and the BTSI index.

The comparison of triglyceride concentrations in gastropods between field and laboratory experiments showed that stores in animals collected in the field were comparable to those measured in animals feeding on breeding food in the laboratory. In comparison, gastropods feeding on algal mat and sedimentary biofilm during the laboratory experiment exhibited 2-fold lower triglyceride concentrations. We suggest that these differences in gastropod triglyceride concentrations between laboratory (for algal mat and sedimentary biofilm) and field experiments were due to the possibility for animals to mix trophic resources in the field. $V$. viviparus is known to "bulldoze" the sediment surface by their crawling and feeding activities (Estragnat et al., 2018), disturbing the vertical organisation of phototrophic and heterotrophic sediment layers (Cook, 1949). Therefore, the non-selective ingestion of sediment by gastropods was associated with the ingestion of a mixture of algae, heterotrophic bacteria, fungi and detritus (Jakubik et al., 2014). As shown by Groendahl \& Fink (2016) in Limnea stagnalis, this mixing diet could have been crucial for $V$. viviparus to achieve a more balanced diet by acquiring all essential microelements (fatty acids or vitamins) they needed for growth. Then, simplified food sources (algal mat or sedimentary biofilm) supplied to gastropods in the laboratory might have limited the acquisition of resources by $V$. viviparus, and therefore the ability to synthetize energy stores such as triglycerides. Such conclusion was consistent with the observations of Jakubik (2009) indicating that V. viviparus feed on varying food sources depending on their availability in the environment.

Although our results highlighted that $V$. viviparus was not a strict generalist in the laboratory, the potential use of multiple food sources and their availabilities during the year in the field allowed $V$. viviparus to maintain triglyceride reserves that were comparable to those obtained in the laboratory with breeding food (positive control). Indeed, the comparison of food sources among periods in the field showed that all foods were quite available in infiltration basin with chlorophyll- $a$ concentrations always higher than $4 \mu \mathrm{g}$ per g of dry sediment and TOC concentrations varying between 0.5 and $0.7 \%$. In these conditions, V. viviparus was able to survive and constitute energy reserves throughout the year, even when the trophic conditions were expected to be the harshest (i.e. low algal levels). In conclusion, the introduction of $V$. viviparus appears as sustainable ecological engineering solution to maintain hydraulic performance of infiltration basins.

\section{Supplementary material}


Online Resource 1 Box-plots of the triglycerides concentrations in gastropods depending on the sex $(n=107)$. Red crosses represent the means. No significant differences were observed (t-test, "sex" effect, $t=-0.51, p$-value $=0.61$ )

\section{Author's contributions}

All authors contributed to the study conception and design. Material preparation, data collection and analysis were performed by Jean-Bastien Gambonnet, Laurence Volatier, Florian Mermillod-Blondin, Frédéric Hervant and Valerian Estragnat. The first draft of the manuscript was written by Valerian Estragnat, Florian Mermillod-Blondin and Laurence Volatier. All authors contributed critically to the drafts and gave final approval for publication.

\section{Ethical approval}

All applicable international, national, and/or institutional guidelines for the care and use of animals were followed.

\section{Funding}

This study was funded by the Lyon Metropole and Veolia Water (Eau du Grand Lyon).

\section{Conflict of Interest}

The authors declare that they have no conflict of interest.

\section{Bibliography}

Barclay, M. C., W. Dall, \& D. M. Smith, 1983. Changes in lipid and protein during starvation and the moulting cycle in the tiger prawn, Penaeus esculentus Haswell. Journal of Experimental Marine Biology and Ecology Elsevier 68: 229-244.

Barranguet, C., B. Veuger, S. A. M. Van Beusekom, P. Marvan, J. J. Sinke, \& W. Admiraal, 2005. Divergent composition of algal-bacterial biofilms developing under various external factors. European Journal of Phycology 40: 1-8.

Bellinger, B. J., M. R. Gretz, D. S. Domozych, S. N. Kiemle, \& S. E. Hagerthey, 2010. Composition of extracellular polymeric substances from periphyton assemblages in the florida everglades. Journal of Phycology 46: 484-496.

Bolnick, D. I., R. Svanbäck, J. A. Fordyce, L. H. Yang, J. M. Davis, C. D. Hulsey, \& M. L. Forister, 2003. The ecology of individuals: incidence and implications of individual specialization. The American Naturalist 
161: 1-28.

Calow, P., 1975. The feeding strategies of two freshwater gastropods, Ancylus fluviatilis Müll. and Planorbis contortus Linn. (Pulmonata), in terms of ingestion rates and absorption efficiencies. Oecologia 20: 33-49.

Carpenter, S., J. Kitchell, \& J. Hodgson, 1985. Cascading trophic interactions and lake productivity. BioScience 35: 634-639.

Clavel, J., R. Julliard, \& V. Devictor, 2011. Worldwide decline of specialist species: toward a global functional homogenization?. Frontiers in Ecology and the Environment. Wiley-Blackwell, 222-228.

Cook, P. M., 1949. A ciliary feeding mechanism in Viviparus viviparus (L.). Journal of Molluscan Studies 27: 265-271.

Costa, O. Y. A., J. M. Raaijmakers, \& E. E. Kuramae, 2018. Microbial extracellular polymeric substances: ecological function and impact on soil aggregation. Frontiers in Microbiology 9.

Cruz-Rivera, E., \& M. E. Hay, 2001. Macroalgal traits and the feeding and fitness of an herbivorous amphipod: the roles of selectivity, mixing, and compensation. Marine Ecology Progress Series 218: 249-266.

Decho, A. W., 1990. Microbial exopolymer secretions in ocean environments : their role ( $\mathrm{s}$ ) in food webs and marine processes. Oceanography and marine biology 28: 9-16.

Decho, A. W., \& D. J. W. Moriarty, 1990. Bacterial exopolymer utilization by a harpacticoid copepod: A methodology and results. Limnology and Oceanography 35: 1039-1049.

Devictor, V., J. Clavel, R. Julliard, S. Lavergne, D. Mouillot, W. Thuiller, P. Venail, S. Villéger, \& N. Mouquet, 2010. Defining and measuring ecological specialization. Journal of Applied Ecology 47: 15-25.

Devictor, V., R. Julliard, J. Clavel, F. Jiguet, A. Lee, \& D. Couvet, 2008. Functional biotic homogenization of bird communities in disturbed landscapes. Global Ecology and Biogeography 17: 252-261.

Elendt, B. P., 1989. Effects of starvation on growth, reproduction, survival and biochemical composition of Daphnia magna. Archiv für Hydrobiologie 116: 415-433.

Estragnat, V., F. Mermillod-Blondin, M. Jully, D. Lemoine, L. Lassabatere, \& L. Volatier, 2018. Does the efficiency of grazer introduction to restore and preserve the hydraulic performance of infiltration basins 
depend on the physical and biological characteristics of the infiltration media?. Ecological Engineering Elsevier 116: 127-132.

Fang, F., W. T. Lu, Q. Shan, \& J. S. Cao, 2014. Characteristics of extracellular polymeric substances of phototrophic biofilms at different aquatic habitats. Carbohydrate Polymers 106: 1-6.

Futuyma, D. J., \& G. Moreno, 1988. The Evolution of Ecological Specialization. Annual Review of Ecology and Systematics 19: 207-233.

Gette-Bouvarot, M., F. Mermillod-Blondin, R. Angulo-Jaramillo, C. Delolme, D. Lemoine, L. Lassabatere, S. Loizeau, \& L. Volatier, 2014. Coupling hydraulic and biological measurements highlights the key influence of algal biofilm on infiltration basin performance. Ecohydrology 7: 950-964.

Gette-Bouvarot, M., L. Volatier, L. Lassabatere, D. Lemoine, L. Simon, C. Delolme, \& F. Mermillod-Blondin, 2015. Ecological engineering approaches to improve hydraulic properties of infiltration basins designed for groundwater recharge. Environmental Science \& Technology 49: 9936-9944.

Graça, M. A. S., L. Maltby, \& P. Calow, 1993. Importance of fungi in the diet of Gammarus pulex and Asellus aquaticus I: feeding strategies. Oecologia 93: 139-144.

Grasshoff, K., M. Ehrdardt, \& K. Kremling, 1983. Methods of Seawater Analysis. Verlag Chemie Berlin.

Groendahl, S., \& P. Fink, 2016. The effect of diet mixing on a nonselective herbivore. PLoS ONE 11: e0158924.

Gust, M., T. Buronfosse, O. Geffard, M. Coquery, R. Mons, K. Abbaci, L. Giamberini, \& J. Garric, 2011. Comprehensive biological effects of a complex field poly-metallic pollution gradient on the New Zealand mudsnail Potamopyrgus antipodarum (Gray). Aquatic Toxicology Elsevier B.V. 101: 100-108.

Hill, W. R., S. C. Weber, \& A. J. Stewart, 1992. Food limitation of two lotic grazers: quantity, quality, and sizespecificity. Journal of the North American Benthological Society 11: 420-432.

Höckelmann, C., \& M. Pusch, 2000. The respiration and filter-feeding rates of the snail Viviparus viviparus (Gastropoda) under simulated stream conditions. Fundamental and Applied Limnology Schweizerbart'sche Verlagsbuchhandlung 149: 553-568.

Holt, R. D., 2009. Bringing the Hutchinsonian niche into the 21st century: ecological and evolutionary perspectives. Proceedings of the National Academy of Sciences 106: 19659-19665. 
Jakubik, B., 2009. Food and feeding of Viviparus viviparus (L.)(Gastropoda) in dam reservoir and river habitats. Polish Journal of Ecology 57: 321-330.

Jakubik, B., 2012. Life strategies of Viviparidae (Gastropoda: Caenogastropoda: Architaenioglossa) in various aquatic habitats: Viviparus viviparus (Linnaeus, 1758) and V. contectus (Millet, 1813). Folia Malacologica 20: $145-179$.

Jakubik, B., P. Koperski, K. L.-P. J. of Ecology, \& U. 2014, 2014. Diversity of mollusca in lowland river-lake system: lentic versus lotic patches. Polish Journal of Ecology 62: 335.

Levins, R., 1968. Evolution in changing environments: some theoretical explorations. Princeton University Press.

Mermillod-Blondin, F., L. Simon, C. Maazouzi, A. Foulquier, C. Delolme, \& P. Marmonier, 2015. Dynamics of dissolved organic carbon (DOC) through stormwater basins designed for groundwater recharge in urban area: Assessment of retention efficiency. Water Research 81: 27-37.

Murphy, J., \& J. P. Riley, 1958. A single-solution method for the determination of soluble phosphate in sea water. Journal of the Marine Biological Association of United Kingdom 37: 9-14.

Poisot, T., J. D. Bever, A. Nemri, P. H. Thrall, \& M. E. Hochberg, 2011. A conceptual framework for the evolution of ecological specialisation. Ecology Letters 14: 841-851.

Rizzo, W. M., S. K. Dailey, G. J. Lackey, R. R. Christian, B. E. Berry, \& R. L. Wetzel, 1996. A metabolism-based trophic index for comparing the ecological values of shallow-water sediment habitats. Estuaries 19: 247256.

Staats, N., L. J. Stal, B. De Winder, \& L. R. Mur, 2000. Oxygenic photosynthesis as driving process in exopolysaccharide production of benthic diatoms. Marine Ecology Progress Series 193: 261-269.

Sterner, R. W., \& D. O. Hessen, 1994. Algal nutrient limitation and the nutrition of aquatic herbivores. Annual Review of Ecology and Systematics 25: 1-29.

Stewart, T. J., J. Traber, A. Kroll, R. Behra, \& L. Sigg, 2013. Characterization of extracellular polymeric substances (EPS) from periphyton using liquid chromatography-organic carbon detection-organic nitrogen detection (LC-OCD-OND). Environmental Science and Pollution Research 20: 3214-3223.

Tsvetkov, I. L., A. P. Popov, \& A. S. Konichev, 2003. Acid phosphatase complex from the freshwater Snail 
Viviparus viviparus L. under standard conditions and intoxication by cadmium ions. Biochemistry (Moscow) 68: 1327-1334.

UNESCO, 1966. Determination of photosynthetic pigments in sea water. Report Scor-Unesco. Working paper 17, Monographs on Oceanographic Methodology. 
Table 1 Elemental composition (total nitrogen, total organic carbon and total phosphorus contents) of the three food sources and the sand used in the aquariums (mean \pm standard deviation)

\begin{tabular}{|l|l|l|l|}
\hline & $\% \mathrm{~N}$ & $\%$ organic C & $\% \mathrm{P}$ \\
\hline Breeding food & $6.5 \pm 0.1$ & $45.1 \pm 0.85$ & $0.74 \pm 0.03$ \\
\hline Algal mat & $1.5 \pm 0.15$ & $19.1 \pm 0.19$ & $0.3 \pm 0.05$ \\
\hline Sedimentary & $0.25 \pm 0.025$ & $2.13 \pm 0.24$ & $0.037 \pm 0.005$ \\
\hline biofilm & & & \\
\hline Sand & $0.013 \pm 0.005$ & $0.036 \pm 0.004$ & 0.0003 \\
& & & 0.000015 \\
\hline
\end{tabular}




\section{Figures}

Fig. 1 Box-plots of the triglyceride concentrations in gastropods (a) and the oxygen consumption rates of gastropods (b) depending on food sources and time. Red crosses represent the means

Fig. 2 Box-plots of chlorophyll- $a$ concentrations (a), TOC (b) and BTSI (c) measured in enclosures (n=6, each value corresponding to the mean calculated from measures performed at the start and the end of the experiment) for each period. Red crosses represent the mean. Different letters represent significant differences among periods obtained with post hoc Tuckey’s HSD tests

Fig. 3 Box-plots of triglyceride concentrations in gastropods at the end of the field experiment (after 6 weeks of experimentation) for each period. Red crosses represent means. Different letters represent significant differences among periods, obtained with post hoc Tuckey’s HSD tests

Fig. 4 Correlation between the triglyceride concentrations and the chlorophyll-a concentrations (a), the TOC (b) and the BTSI (c) 

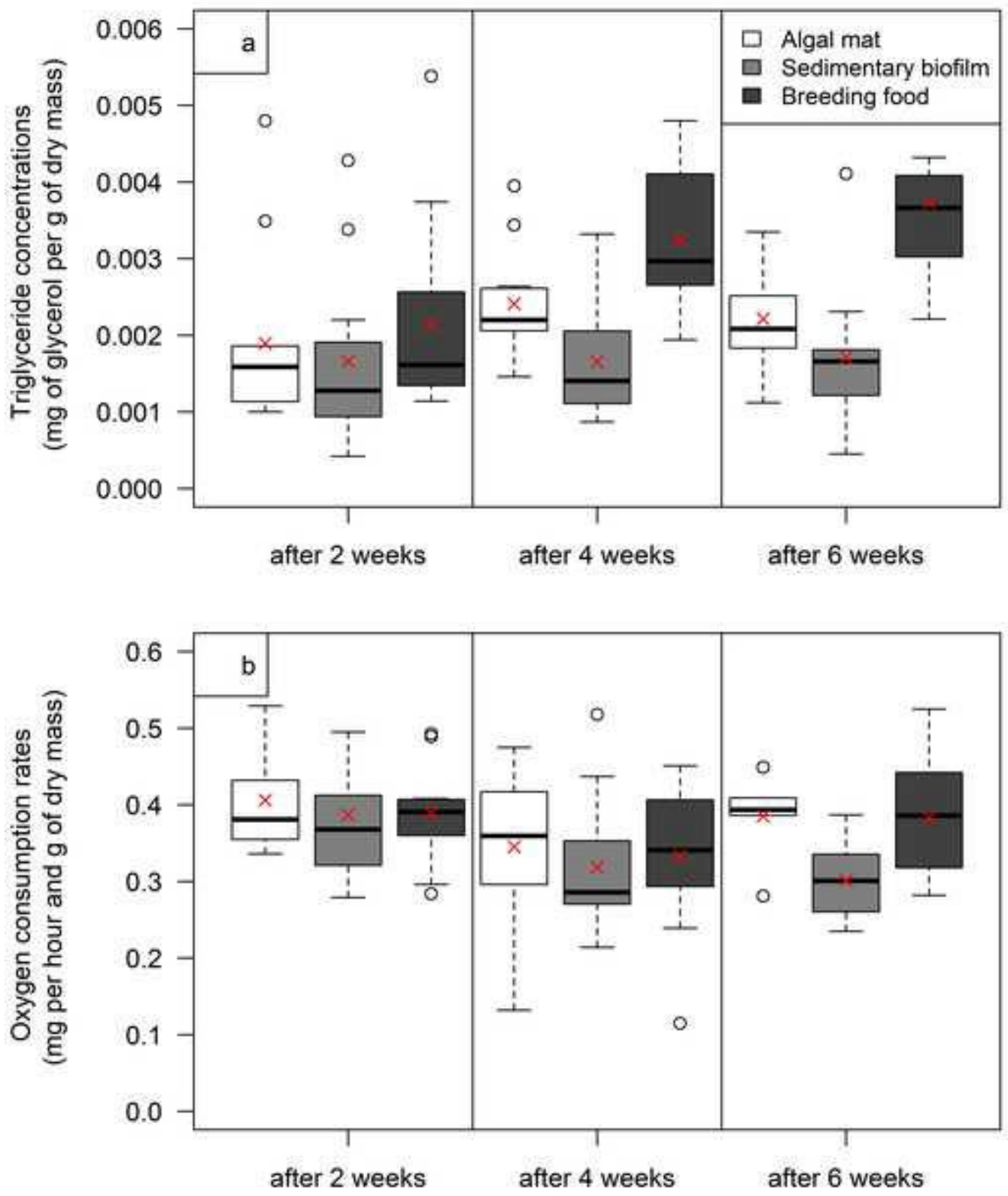

Figure 1 

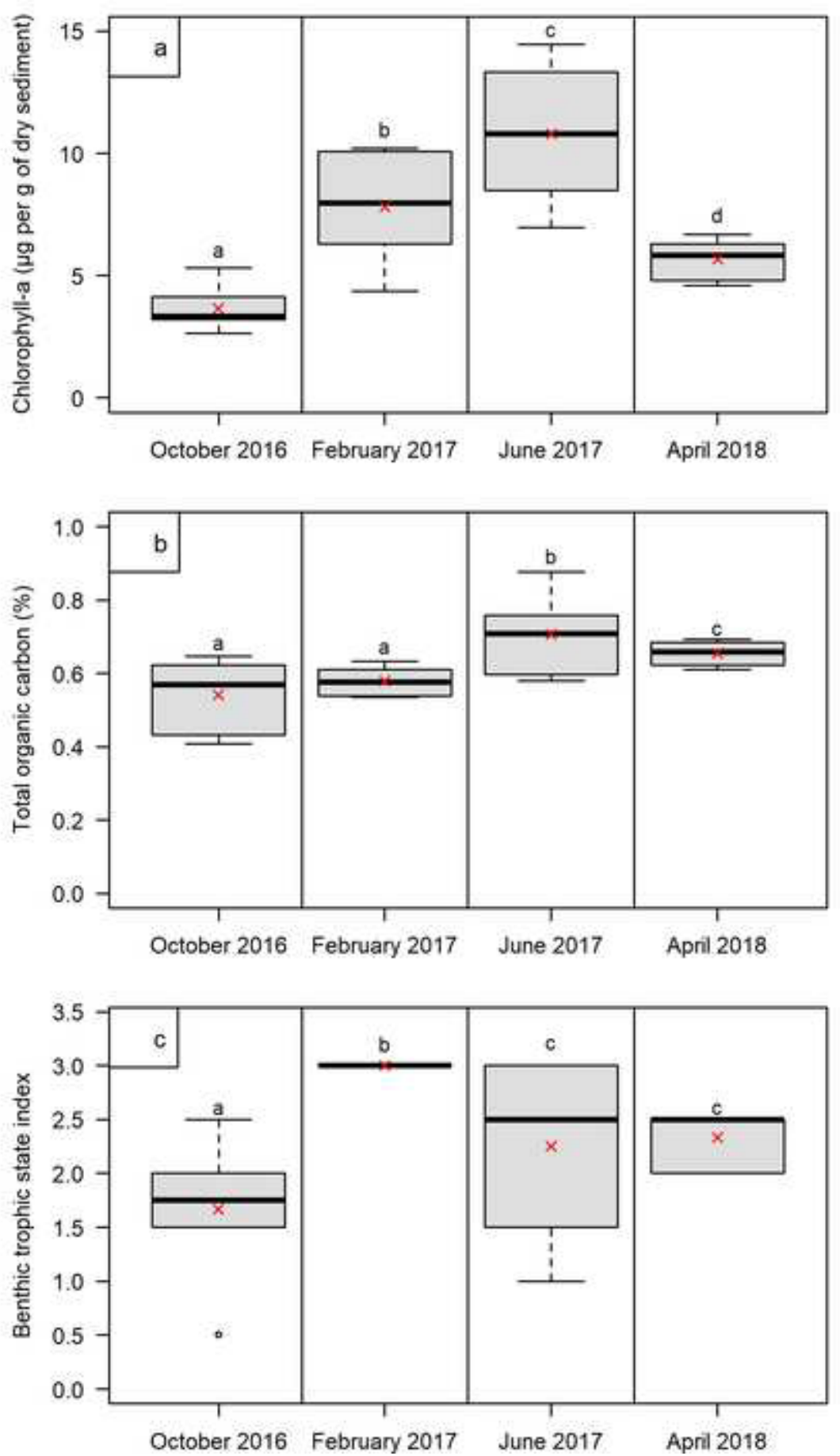

Figure 2 


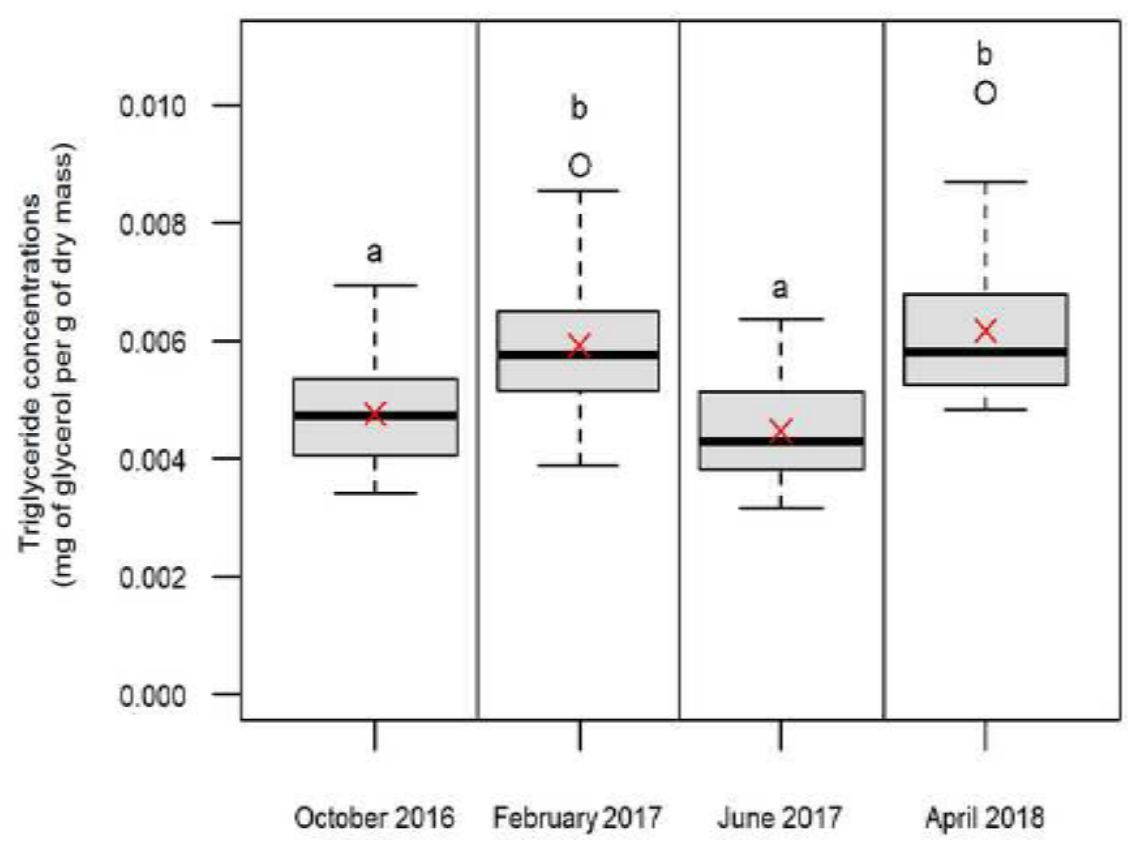

Figure 3

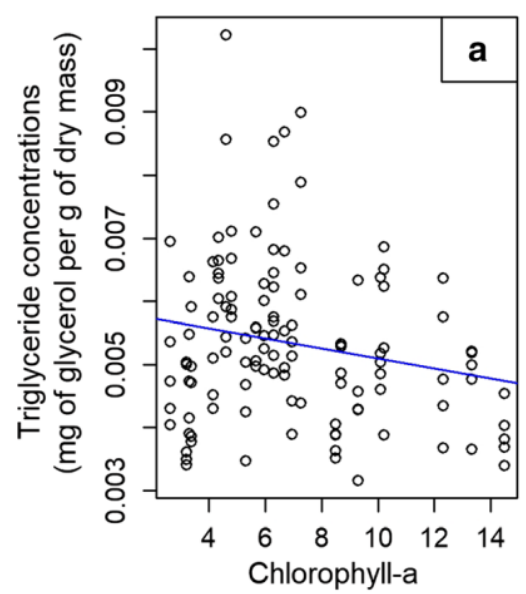

( $\mu \mathrm{g}$ per $\mathrm{g}$ of dry sediment)
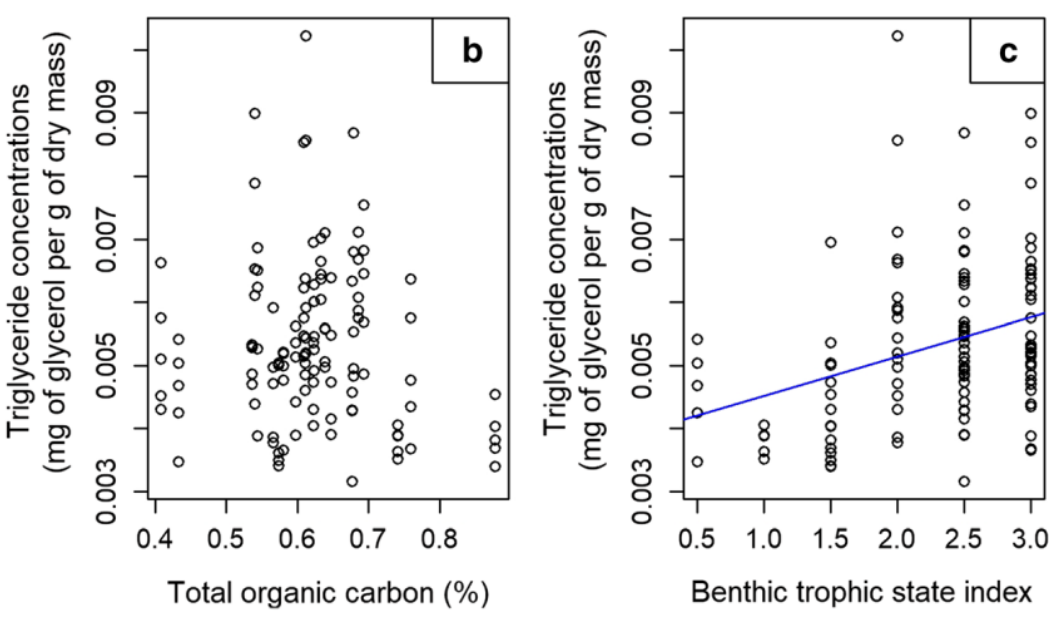

Figure 4 